\title{
A new Apotomopterus Hope, 1838 species (genus Carabus Linnaeus, I758) from South Guangxi province, China (Coleoptera Carabidae)
}

\author{
Ivan Rapuzzi
}

Via Cialla 47, 33040 Prepotto, Udine, Italy; email: info@ronchidicialla.it

\begin{abstract}
A new species of the genus Carabus Linnaeus, 1758 (Coleoptera Carabidae), belonging to the subgenus Apotomopterus Hope, 1838, from South Guangxi province, China, is described and figured.
\end{abstract}

KEY WORDS Coleoptera; Carabidae; Carabus; Apotomopterus; new species; Guangxi; China.

Received 26.08.2020; accepted 12.09.2020; published online 18.09.2020

\section{INTRODUCTION}

The examination of some carabid beetles (Coleoptera Carabidae) collected in southern China (Guangxi province) gave me the opportunity to identify a new species of the genus Carabus Linnaeus, 1758, belonging to the subgenus Apotomopterus Hope, 1838, closely related to clermontianus species group.

The new species has biogeographical significance because only very few Apotomopterus species inhabit that subtropical area of the Southernmost part of Guangxi Province (Deuve, 2013; Kleinfeld, 2019).

\section{RESULTS}

\section{Systematics}

Ordo COLEOPTERA Linnaeus, 1758

Subordo ADEPHAGA Schellenberg, 1806

Familia CARABIDAE Latreille, 1802

Subfamilia CARABINAE Latreille, 1802

Genus Carabus Linnaeus, 1758
Subgenus Apotomopterus Hope, 1838

Carabus (Apoptomopterus) argenticornis n. sp. (Fig. 1) - http://zoobank.org:act:D061445B-55D2-48 FC-AC11-84BBBBC078CB

EXAMINED MATERIAL. Holotype male, China, South Guangxi province, Qinzhou city, Mt. Shiwandashan, $1200 \mathrm{~m}, \mathrm{~V} .2020$. The holotype is temporarily housed at the author's collection (Prepotto, Udine, Italy) waiting to be definitively deposited in a public Institution.

Description of Holotype. Length including mandibles $38 \mathrm{~mm}$, maximum width of elytra: 13 $\mathrm{mm}$.

Upper surface uniformly black, quite mat, the primary tubercles of elytra shiny. Ventral surface, legs, palpi, antennae, and mandibles black.

Big and quite stout head; head surface very strongly punctured and very strongly wrinkled. Eyes very convex of hemispheric shape. Very long palpi, penultimate segment of the labial palpi with two or three-setae. Long antennae protruding beyond the half of the elytra; segments 5 to 11 with a dense white pubescence. Sides of the prosternal 
process fully margined. Mesosternum strongly rugulose with a dense pubescence.

Big pronotum of sub-hexagonal shape, transverse (1.3 times as broad as long); maximum width at the middle, strongly sinuated before the base and regularly rounded till the apex; sides fully margined and bent upwards; hind angles large and rounded, not protruding behind its base; upper surface uniformly roughly punctured.

Elytra of oval shape, quite short; disc convex; shoulders very large and rounded; apex quite acuminated. Sculpture of elytra of triploid heterodyname type: primary intervals strongly convex forming long links interrupted by foveae, these links have a characteristic spinula at its base; secondary and tertiary intervals are smaller, forming range of grains of the same size; strongly punctured striae. Legs very long and strong.

Aedeagus (Figs. 2, 3) of subcylindrical shape, sub rectilinear in the medial part of the apical lobe; apex strongly bent, forming a tooth large and acuminate.

ETYMOLOGY. The given name wants to point out the strong white pubescence of antennae.

REMARKS. The new species is close related to C. clermontianus Breuning, 1933 and C. yaophilus Deuve, 1990 with forms a homogeneous group of species under a morphologically and biogeographically point of view (Breuning, 1933; Deuve, 1990). From C. clermontianus, it is easily distinguished by: larger head, surface strongly punctured, longer neck, larger and more convex eyes; segments 5 to 11 of antennae with a longer but less dense pubescence; mesosternum strongly rugulose with a dense pubescence; sides of prosternal process fully margined; bigger pronotum of subhexagonal shape, anteriorly rounded, hind angles larger and rounded; shorter and convex elytra; sculpture of elytra of heterodyname type; apex of male aedeagus shorter and acuminated. From $C$. yaophilus, it is distinguished by: stouter head, surface strongly punctured; stronger antennae, segments 5 to 11 with longer and less dense pubescence; mesosternum less rugulose; sides of prosternal process fully margined; more transverse pronotum; hind angles larger and rounded; larger and shorter elytra; disc of elytra convex; different sculpture of elytra: secondary intervals forming a range of grains (uninterrupted costae in

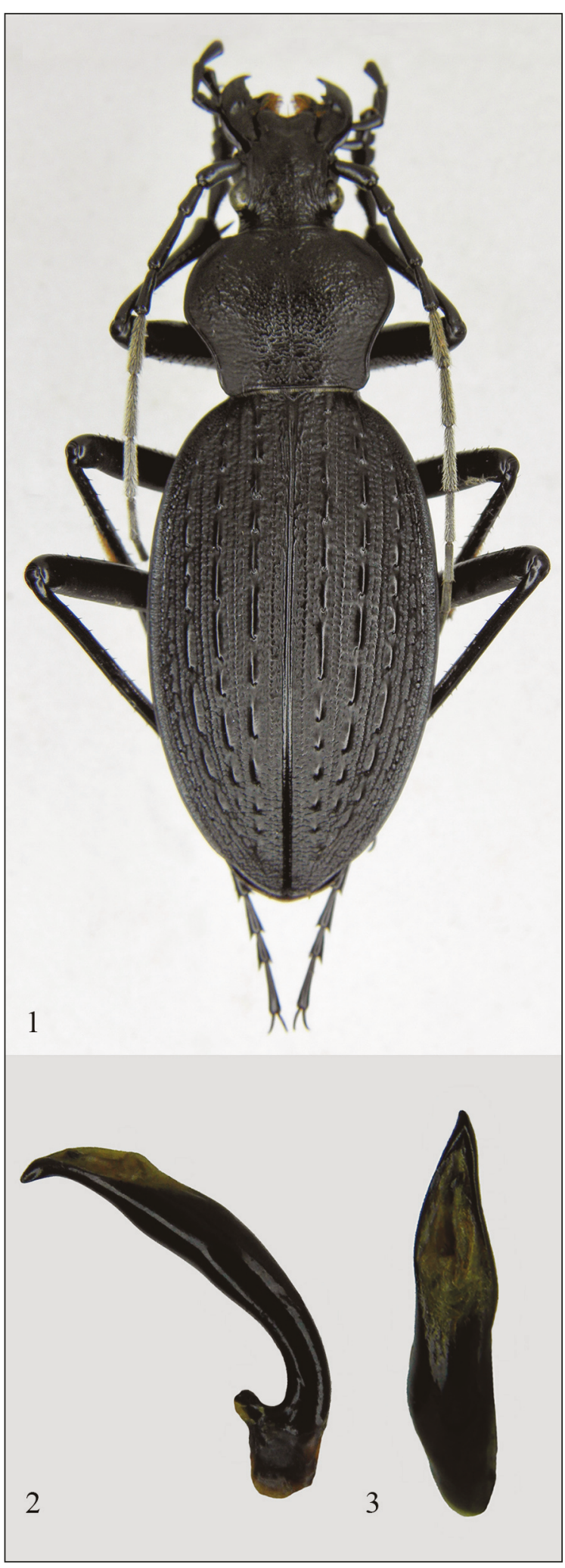

Figures 1-3. Carabus (Apotomopterus) argenticornis $\mathrm{n}$. sp. Holotype. Fig. 1: habitus; Fig. 2: aedeagus in lateral view. Fig. 3: aedeagus in dorsal view. 
yaophilus); apex of male aedeagus strongly acuminated and strongly curved.

\section{REFERENCES}

Breuning S. von, 1933. Zehn neue asiatische Caranben. Entomologisches Nachrichtenblatt, Troppau, 7: 2127.
Deuve Th., 1990. Diagnose préliminaire d'un nouveau Carabus du Guangxi (Col. Carabidae). Nouvelle Revue d'Entomologie (N. S.), 7: 162.

Deuve Th., 2013. Cychrus, Calosoma et Carabus de Chine. Pensoft Series Faunistica no 105: 307 pp.

Kleinfeld F., 2019. Apotomopterus. Monographische Übersicht über das Subgenus Apotomopterus Hope, 1838 des Genus Carabus Linnée, 1758. Dr. Frank Kleinfeld. 4 Auflage: 309 pp. 
